\title{
Study of the utilization of Azolla microphylla as alternative feed by Tilapia farmers in Panjalu Ciamis, West Java Province, Indonesia
}

\author{
Ganjar Wiryati ${ }^{*}$ \\ ${ }^{1}$ Fisheries Extension Study Program, The Jakarta Technical University of Fisheries, Indonesia
}

\begin{abstract}
Feed is the most significant component of tilapia culture production costs. Various attempts have been made to reduce this cost with alternative feed, including A. microphylla. The research aims to encourage changes in the level of knowledge, attitudes, and skills of fish cultivators about utilization and cultivation of Azolla through the demonstration ponds (Dempond) and increase the production of tilapia by increasing the stocking density and the use of $A$. microphylla feed. The research was conducted from March 2nd to May 15th, 2021, in Panjalu Sub District, Ciamis Regency, West Java Province. Data were collected by purposive sampling, with observation and interview methods. The data consists of primary and secondary data. The data analysis was carried out in a descriptive qualitative manner. The results showed a change in fish cultivators' knowledge about the benefits and cultivation of A. microphylla by an average of $20.28 \%$, a change in target attitudes by $5.1 \%$, and skill improvement by $28 \%$. There was an increase in tilapia yield from the initial total weight of $121.25 \mathrm{~kg}$ to $226.1 \mathrm{~kg}$ using $24 \mathrm{~kg}$ of $\mathrm{A}$. microphylla as a feed additive for 60 days of culture.
\end{abstract}

\section{Introduction}

The characteristics of the Panjalu sub-district are in the form of highlands and dominant mountains. Some people do aquaculture business with ponds in the yard of their houses, but still, on a small scale, cultivation is done long enough with varied commodities such as carp and tilapia. Tilapia is one type of fish consumption that has considerable potential to be developed because it has a high economic value and has a strong commodity value in freshwater fish farming business activities (Figure 1). Aquaculture is one of the business types which has much demand by the community. Fish is a source of animal protein with a protein content between $15.32-18.80 \%$. Animal protein obtained from tilapia fish is very beneficial. The demand for tilapia market consumption in the Ciamis is as much as 10

${ }^{*}$ Corresponding author: ganjar1667@gmail.com 
tons/year. Tilapia production only fulfills $10 \%$ of the existing market demand. So, $90 \%$ of the demand is imported from the outside region. The Panjalu sub-district has a 50,063 ha area. A pond area of 98,795 ha supports the potential fisheries. Availability of abundant water throughout the year flows from the Rompe river. A technology used by the cultivators is still traditional. The average production of tilapia cultivation is as much as 1.6 tons/year. The demand for tilapia's fish consumption in Ciamis Regency is as much as 10 tons/year. The lack of feed availability causes the low production of tilapia So, it impacts the number of cost production incurred [5]

A. microphylla is a nail plant that floats on the water surface (Figure 2). This plant has tiny leaves overlapping, the surface of the leaves is soft, it is bright green, and it has many spores. The type of Azolla plant, which the most commonly encountered and utilized are Azolla pinnata and Azolla microphylla [6]. The nutritive value of Azolla contains high levels of protein between 24-30\% [6]

Human resources at Panjalu sub-district are fisheries cultivator, which is \pm 280 fisheries households with diverse business segments and commodities, the business being carried out is still traditional. The fisheries cultivator in Panjalu sub-district still does not know about alternative feeds that can maintenance the tilapia and make the fish cultivations better. The research aims to encourage changes in the level of knowledge, attitudes, and skills of fish cultivators about the utilization and cultivation of Azolla through the demonstration ponds (Dempond).

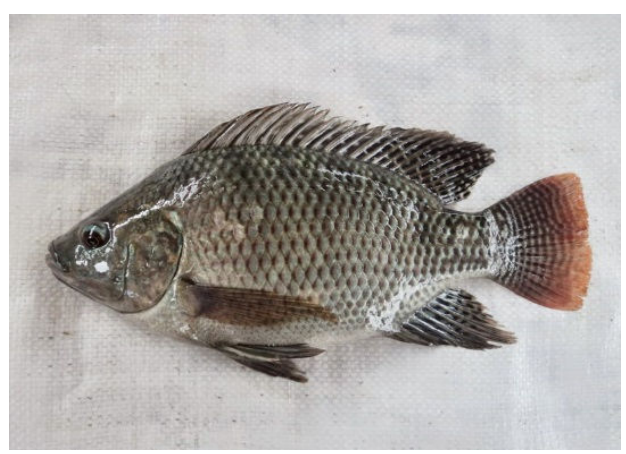

Fig. 1. Tilapia (Oreochromis niloticus)

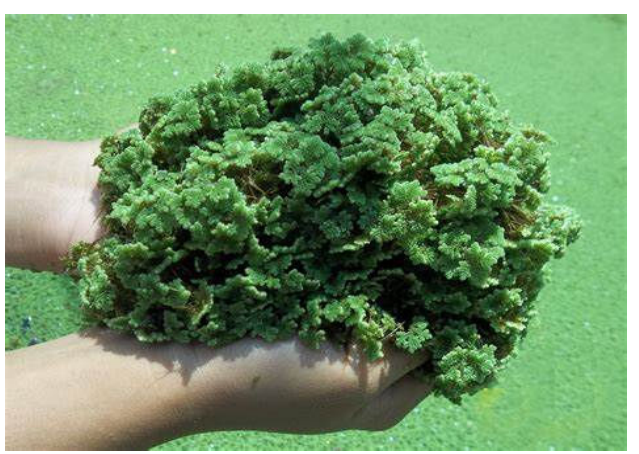

Fig. 2. Azolla (A.microphylla)

\section{Materials and methods}

Hunjungwangi Group researched Panjalu Sub-district, Ciamis Regency, West Java Province. The research was conducted for three months, from March $2^{\text {nd }}$ to May $15^{\text {th }}, 2021$. Determination of samples is using a purposive sampling method towards the group of tilapias cultivators who are still active - the target of respondents counseling is 14 fisheries households of the Hunjungwangi Group'smembers. There are ten fish cultivators involved in all activities.

This study observed the utilization of Azolla as an alternative feed for tilapia cultivation by using demonstration pond (Dempond) methods. Dempond activities were carried out in the different ponds. Pond (A) was given treatment according to the Indonesian National Standard of Tilapia Cultivation and given additional feed Azolla. In comparison, pond (B) was a pond of tilapia cultivators in usual that given treatment according to commons applied by the community in Panjalu sub-district Ciamis. The treatment of ponds was compared with the application of Azolla's feed, pond (A) given Azolla's feed as much as 1.2 kilograms $(\mathrm{kg})$ once three days, and commercial feed (Hi-Provite 781-2 with a protein content of $27-32 \%$ ) as much as $3 \%$ every day. At the same time, pond (B) was not fed by 
Azolla and given commercial Feed (Hi-Pro vite781-2 with a protein content of 27-32\% every day) [20]. Water quality measurements were taken once a week to find out the quality of water in Dempond.

Demonstration activities on how to cultivate Azolla were carried out using a pond's soil with a size of $3 \mathrm{~m} \times 3 \mathrm{~m} \times 0.5 \mathrm{~m}$. The pond was cleaned and dried, put in chicken fertilizer with a dose of 350 grams $/ \mathrm{m}^{2}$ and, filled with water until around $20 \mathrm{~cm}$. The preparation of pond media took three days until the fertilizer could be mixed well and did not release the odors. Then the seedlings were stocked with a solid spread of 100 grams $/ \mathrm{m}^{2}$.

Evaluation of tilapia cultivation Dempond activities using Azolla feed includes aspects of knowledge, attitude, and skills with instruments in the form of questionnaires given at the beginning (pre-test) and the end (post-test) that have been validated. The data collected consists of primary and secondary data. Primary data is collected by in-depth interviews with respondents counseling, extension, and the village leader. Secondary data is obtained from the extension activity report, and data report in the Sub-District.

Evaluation activities are conducted twice, at the beginning which before the activity is carried out, to look at the flow of information that is already in the target community, and the second evaluation is carried out after the activity takes place to see the changes after the flow of information is carried out. These aspects are evaluated in this activity, such as knowledge, attitude, and skills aspects.

Evaluation activities of knowledge aspect and attitudes aspect were using the following formula below. Evaluation activities of skills aspects were to determine the business situation from the economic side using business analysis. Business analysis is determined by Break-Even Point (BEP), Revenue/cost ratio.

Knowledge aspect:

$$
\begin{gathered}
\text { Change }=\text { End score }- \text { score Beginning } \\
\text { Likers scale }=\frac{\text { initial score-Final score }}{\text { Initial score }} \times 100 \%
\end{gathered}
$$

Attitude aspect:

$$
\text { Likers scale }=\frac{\text { Total Score }}{\text { Total maximum }} \times 100 \%
$$

Break-even point (BEP) is a term in accounting that refers to the situation where a company's revenues and expenses were equal within a specific accounting period. It means that there were no net profits or net losses for the company - it "broke even."

break-even point in units compute by the following formula below

$$
\text { Break-even Point }(\text { Units })=\text { Fixed Costs } /(\text { Revenue Per Unit }- \text { Variable Cost Per Unit })
$$

break-even point in dollars computed by the following formula below:

$$
\text { Break-even Point (Sales in dollars) = Fixed Costs / (Sales Price per Unit x BEP in Units) }
$$

Return Cash Ratio $(\mathrm{R} / \mathrm{C})$ is the total revenue ratio to the total amount of costs incurred during a period. A business is considered profitable if the $\mathrm{R} / \mathrm{C}$ ratio $>1$.

$\mathrm{R} / \mathrm{C}=\mathrm{TR} / \mathrm{TC}=$ With the results of the $\mathrm{R} / \mathrm{C}$ calculation obtained by 1.6 , this hydroponic business can provide benefits. Every IDR 1.00 capital will return IDR 1.60 


\section{Results}

Individual characteristics are traits that a person displays that relate to all aspects of his life in his world or environment [25]. The characteristics of a person who is used as a target can be seen from age aspects, formal education, and business experience.

The observation results on the characteristics of fish cultivators in Panjalu District of Ciamis Regency can be seen in Table 1.

Tabel 1. Age categories, education level, and target business experience.

\begin{tabular}{|c|c|c|c|}
\hline \multirow{2}{*}{ Age responded } & Category (year) & Standard (year) & $\begin{array}{c}\text { Sum } \\
\text { (people) }\end{array}$ \\
\cline { 2 - 4 } & Young & $\mathrm{X}<(34)$ & 0 \\
\cline { 2 - 4 } & Adult & $(34)=>\mathrm{X}<(52)$ & 7 \\
\hline \multirow{2}{*}{ Old total } & $\mathrm{X}>(52)$ & 3 \\
\hline \multirow{2}{*}{ Level of Education } & Low total & $\mathrm{X}<(1)$ & 0 \\
\cline { 2 - 4 } & Medium & $(1)=>\mathrm{X}=<(3)$ & 10 \\
\cline { 2 - 4 } & High & $\mathrm{X}>(3)$ & 0 \\
\hline \multirow{2}{*}{ Business Experience } & New & $\mathrm{X}<(1)$ & 8 \\
\cline { 2 - 4 } & Medium & $(1)=>\mathrm{X}=<(11)$ & 10 \\
\cline { 2 - 4 } & Old total & $\mathrm{X}>(11)$ & 0 \\
\hline
\end{tabular}

Notes: 0= Unschool, $1=$ Elementary school,2: Middle school, 4: Bachelor, 5: Master, $6:$ Doctoral

Dempond activities in different ponds, i.e., Pond (A) is a pond that is given treatment according to literature. At the same time, pond (B) was a pond of tilapia cultivators in usual that given treatment according to commons applied by the community in Panjalu subdistrict Ciamis. The results of treatment pond (A) and untreated pond (B) Dempond activities can be seen in detail in Table 2 .

Table 2. Results of Treatment Pond A and Un-Treated Pond B

\begin{tabular}{|c|c|c|c|}
\hline No & Parameter & Pond Treatment (A) & Untreated Pond (B) \\
\hline 1 & Pond size $\left(\mathrm{m}^{2}\right)$ & 140 & 140 \\
\hline 2 & Water depth $(\mathrm{cm})$ & 100 & 100 \\
\hline 3 & Maintenance duration (days) & 60 & 60 \\
\hline 4 & Dosage of lime $(\mathrm{kg})$ & 3.4 & - \\
\hline 5 & Fertilizer dosage $(\mathrm{kg})$ & 7 & - \\
\hline 6 & Initial fish size $(\mathrm{cm})$ & $12-14$ & $12-14$ \\
\hline 7 & Stocking density $\left(\mathrm{fish} / \mathrm{m}^{2}\right)$ & 8 & 8 \\
\hline 8 & Total number (fish) & 1200 & 1200 \\
\hline 9 & Feed type & $\begin{array}{c}\text { commercial feed }+ \\
\text { Azolla }\end{array}$ & commercial feed \\
\hline 10 & $\begin{array}{l}\text { Amount of commercial feed } \\
\text { Feed (\%/day) }\end{array}$ & $\begin{array}{l}3 \% \text { (according to } \\
\text { sampling results) }\end{array}$ & $\begin{array}{l}\text { 3\% (according to sampling } \\
\text { results) }\end{array}$ \\
\hline 11 & Additional Azolla (kg/3 days) & 1,2 & - \\
\hline 12 & Total commercial feed $(\mathrm{kg})$ & 198,04 & 150 \\
\hline 13 & Number of harvests (fish) & 1138 & 970 \\
\hline 14 & Production $(\mathrm{kg})$ & 226.1 & 121,25 \\
\hline 15 & Final productivity $\left(\mathrm{kg} / \mathrm{m}^{2}\right)$ & 1,50 & 0,86 \\
\hline 16 & Average harvest/fish weight (gr) & 198,70 & 121.25 \\
\hline 17 & Survival rate $(\mathrm{SR})(\%)$ & 94 & 80 \\
\hline 18 & FCR & 1,1 & 2,4 \\
\hline 19 & Temperature ${ }^{\circ} \mathrm{C}$ & 25.7 & 24.9 \\
\hline 20 & $\mathrm{pH}$ & 7.1 & 6.7 \\
\hline
\end{tabular}


Comparison of the results of pilot pond trials in Table. 2. shows the results of Dempond activities that have been implemented. Dempond activities are carried out in the different ponds. Pond (A) is given treatment are following with the reference SNI Cultivation Tilapia fish and given Additional Feed Azolla. While pond (B) is a pond of farmers in general, the treatment is according to what is applied by the community in Panjalu sub-district Ciamis.

Business analysis needs to be done on business activities to find out the results in the form of financial results in the form of profits, so the provided innovation can benefit and increase revenue for the target. The results of the Dempond business analysis calculation can be seen in detail in Table 3 .

Table 3. Results of Dempond business analysis calculations

\begin{tabular}{|c|l|r|r|}
\hline No & \multicolumn{1}{|c|}{ Type of cost } & \multicolumn{1}{c|}{ Pond A } & \multicolumn{1}{c|}{ Pond B } \\
\hline 1 & Investment cost (IDR) & $3.400 .000,-$ & $3.340 .000,-$ \\
\hline 2 & Depreciation Expense/ month (IDR) & $283.332,-$ & $278.332,-$ \\
\hline 3 & Depreciation/cycle expenses (IDR) & $566.664,-$ & $556.664,-$ \\
\hline 4 & Fixed Cost (IDR) & $553.751,-$ & $553.751,-$ \\
\hline 5 & Variable Costs (IDR) & $3.047 .200,-$ & $2.700 .000,-$ \\
\hline 6 & Production Costs (IDR) & $3.047 .200,-$ & $3.253 .751,-$ \\
\hline 7 & Receipt (IDR) 6,828,000,- 3,637,500,- & $6.828 .000,-$ & $3.637 .500,-$ \\
\hline 8 & Advantages (IDR) & $3.007 .649,-$ & $401.749,-$ \\
\hline 9 & BEP IDR (IDR) & $999.550,-$ & $2.215 .004,-$ \\
\hline 10 & BEP unit (IDR) & $37.89,-$ & $20.345,-$ \\
\hline 11 & R/C Ratio (\%) & 1.7 & 1.1 \\
\hline 12 & Payback Periode (year) & 1.13 & 8.3 \\
\hline
\end{tabular}

Evaluation is carried out to find out the changes that occurred and were experienced by the extension target, while the aspect evaluated in this activity is the knowledge aspect. The results of the evaluation of knowledge aspect respondent after carrying out a demonstration on the theme of alternative feed used Azolla to enlarge tilapia.

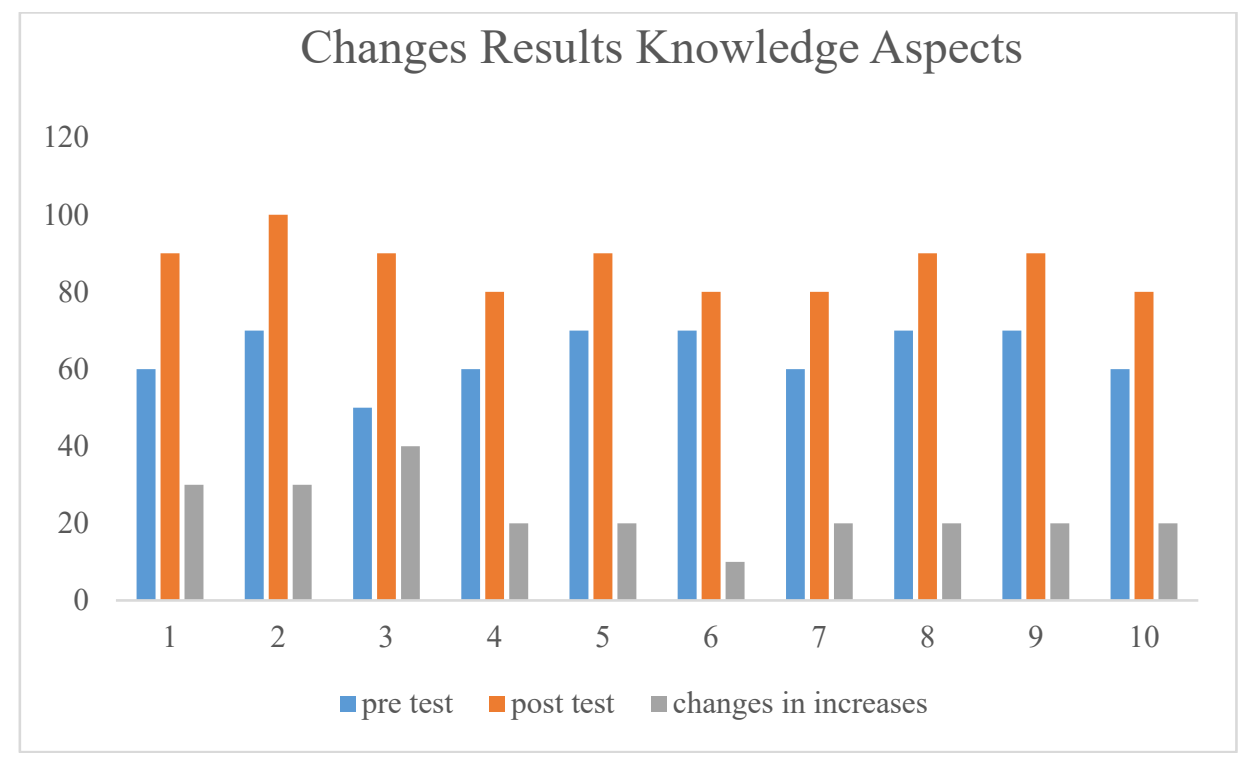

Fig. 3. Changes result from knowledge aspects of fish cultivators 
Types of Azollae cultivated type A. microphylla. Fertilization is carried out over once ten days. A quarter dose is given at the beginning of fertilization, intended to maximize the growth of Azolla. Azolla that has been cultured for the next week can be harvested. Harvesting is done every three days with a harvest of $1.2 \mathrm{~kg}$ to be given additional feed. Harvesting is only done on one side of the ponds, giving the Azolla a chance to keep growing. Azolla is given for 1200 fish (Table 2). The use of Azolla can be carried out for two months, with a total consumption of Azolla is $24 \mathrm{~kg}$.

\section{Discussions}

Characteristics of fish farmer Tilapia cultivators located in the Panjalu region are seen in several characteristics, including age, level of education, and business experience. Characteristics are characteristics or characteristics of the inherent natural self of a person that includes age, level of education, land area, and experience you have to try to farm [22]. Table 1. Age less than 34 years and 34 to 52 years of age is balanced as a productive age. This result follows the Indonesian Central Bureau of Statistics states that the productive age is between 15-64 years.

One of the factors that influence the productivity of farmers is the age factor [2]. The age that is still in productive period usually has a higher level of work productivity in managing a business, have physical abilities, and good mindset compared to the old labor so that the physical has become weak and limited. Productive farmers want to develop fisheries, and fishery activities can be followed and then applied. The target belongs to this category as many as seven people. It is necessary to be conscious and plan efforts in realizing the learning situation. The learning process encourages learners to explore their potential so that they have various strengths in the field of religion, spirituality, self-control, personality, intelligence, noble morals, and the skills required of themselves, society, nation, and country [10]. The characteristics of the target based on the level of education that dominates are the level of education elementary, junior high, high school or fall into the category of "MEDIUM." Every citizen is obliged to study for six years [10]. Target characteristics based on length of effort, dominant at one to 11 years, fall into the category of "MEDIUM." [6] business experience with an average length of 11 years, then showed good cultivation ability in running his business.

Biotic and abiotic factors during maintenance significantly affect the life rate of tilapia, including water quality, feed, competition/competitors, human handling, and density of dispersal. As well as biotic factors, abiotic factors that include physical and chemical properties of the water [15] stated that water quality management is the main component that must be considered in improving production results. Therefore, monitoring water quality periodically during Dempond activities is carried out [15]. The following are the results of water quality observations that have been made in treatment pond (A) and nontreatment pond (B) during \pm 60 days of maintenance.

A demonstration of how to cultivate Azolla as an additional feed is done. That activity aims to show farmers that Azolla plants can be given to fish and can reduce production costs. Azolla feed is given only as a companion protein to suppress pellet feed, not as the main protein in maintenance. The skills of cultivators are improved.

Fish growth in the treatment pond (A) with intensive commercial feeding coupled with Azolla feed, faster growth, and higher survival than fish that are only given commercial feed. Following [8], feed is one of the most critical factors to the growth and survival of cultivated fish. So, at the end of the maintenance period, fish in the treatment pond (A) has reached the target production weight of up to almost $200 \mathrm{~g} /$ tail, while the pond without new treatment reaches a weight range of $130 \mathrm{~g} /$ tail. 
The business aspect of the results of business analysis in the treatment pond (A) and without treatment Pond (B) shows the marginal acceptance reached IDR 6.828,000. This value is influenced by the result of production, which differs between the treatment and untreated pond. The profit in 1 cycle reaches IDR 3.007,649, while the un-treated pond also has a profit, but it is deficient when harvested with a maintenance time limit simultaneously with the treatment pond, which is 60 days.

Based on the initial and final evaluation results and evaluation from aspects of knowledge on the activities of Dempond cultivation of tilapia, there has been a change in the average knowledge of $20.28 \%$. This result happened because at the time of implementation of the active target and focused following each stage. There was a high sense of curiosity about the tilapia enlargement Dempond.

The influence of knowledge has increased in general related to education. Evaluation results on the aspect of Dempond attitude of tilapia cultivation have changed the target's attitude with a score of 428 to 450 targets to change the score by $5.1 \%$. The attitude of the target changed after the tilapia cultivation Dempond. The formation of attitudes is still related to experience because the process will increase the knowledge that is already possessed and include the experience of using new technologies [13].

An evaluation of the skill aspect was conducted to determine the skill level of respondents in the tilapia cultivation Dempond activity. Assessment indicators on the skill aspects of tilapia cultivation Dempond activities include accuracy, speed, and accuracy regarding tilapia cultivation techniques and how to apply feed Azolla.

The evaluation results of skill aspects showed an increase in initially professional skills by $7 \%$ to $35 \%$. In contrast, the unskilled category decreased from $65 \%$ to $3 \%$. According to [13], the factors that affect skills are experience and age. With the majority of productive ages, age-related abilities are a factor in carrying out an activity and can also be a benchmark for knowing the activities of a person doing work. In addition to the evaluation of activities, both in the aspects of knowledge, attitudes, and skills, are also carried out impact evaluation, namely evaluation of innovation adoption by directly observing the level of acceptance and application of targets to the material/innovation that has been delivered in the process of extension activities.

\section{Conclusion}

The evaluation results conducted on fish cultivators as many as ten people on Dempond utilization of Azolla showed changes in knowledge improvement by $20.28 \%$, attitude improvement by $5.1 \%$, and skills improvement by $29.7 \%$. Production of tilapia fed commercial feed and added by Azolla was higher $(226.1 \mathrm{~kg})$ than tilapia fed only by commercial feed $(121.25 \mathrm{~kg})$ for 60 days rearing period.

\section{References}

1. A. Hardjamulia, Cultivation of the department of agriculture (SUPM, Bogor, 1978)

2. BPS. Districts Panjalu in 2018 (Badan Pusat Statistik, Regency Ciamis, 2021)

3. D. Tanto, S. M. Dewi. J. Rekayasa Sipil (2012)

4. Effendi, Mulyadi. Budidaya perikanan (Universitas Terbuka, Jakarta, 2009)

5. E. Kusumawati, S. Rahardjo. J. Ilmu Kesehatan Masyarakat 4, 2 (2011).

6. Gilang, Potential identification districts Panjalu, Regency Ciamis (in Bahasa Indonesia) (The Jakarta Technical University of Fisheries Indonesia, Banten, 2020).

7. Haetami, Sastrawibawa, Rev. Bionatura, 7,3 (2005)

8. H. Radiatul, J. Aquat. Sci. 9,1 (2021) 
9. Kepmen Ministry of marine affairs and fisheries Number 14 of 2012

10. Khairuman, Smart book cultivation of 15 fish consumption (Gramedia Main Library, Tangerang, 2013).

11. Khairuman, Khairul. Tilapia cultivation (PT. Agro Media Pustaka, Jakarta, 2013)

12. Law of the Republic of Indonesia Number 16 of 2006 on the Agricultural Extension System, Fisheries and Forestry

13. N. Ningsih, La Nalefo, I. A Munawasih, J. Village Building and Agriculture (2019)

14. S. Gayatri, B. T. Eddy, Fadhilah M. L, J. Agrisocionomic Sosial Ekonomi Pertanian (in Bahasa) (2017)

15. S. Gunawan. Catfish cultivation success (Penebar Swadaya, Jakarta, 2016)

16. S. S. Monalisa, I. Minggawati, J. Trop. Fish 5, 2 (2010)

17. S. Padmowihardjo. J. Counseling 2,1 (2006)

18. SNI 7550 Calm pond class tilapia production (2009)

19. Sukirno, Sadono. Macroeconomic theory introductory Third Edition (Rajawali Pers, Jakarta, 2012)

20. Suwandi. Participatory extension (Cekza Blog, Bogor, 2006)

21. Suwondo, Darmadi, J. Biogenesis 17, 1 (2021)

22. T. Mardikanto, Extension of agricultural system (Eleven March University Press, Surakarta, 2009)

23. Runtuwarow V, Master Thesis. Bogor (ID): IPB University, (2002).

24. Burano, R. S, T. Y. Siska, J. Menara Ilmu 8, 10 (2019)

25. D. E Yani, L. E. Ludivica, R. Noviyanti, J. Matematika, Sains dan Teknologi (2010) 